\author{
В.Й. Климченко ${ }^{1}$, О.С. Маляренко ${ }^{1}$, О.В. Бєлавін ${ }^{2}$, В.В. Джус ${ }^{1}$ \\ ${ }^{1}$ Харківський національний університет Повітряних Сил ім. І. Кожедуба, Харків \\ ${ }^{2}$ Командування Повітряних Сил Збройних Сил Украӥни, Вінниияя
}

\title{
УДОСКОНАЛЕННЯ МЕТОДУ ОПОСЕРЕДКОВАНОГО ВИМІРЮВАННЯ ТОЧНІСНИХ ХАРАКТЕРИСТИК ОГЛЯДОВИХ РЛС
}

\begin{abstract}
У зв'язку з обмеженими можливостями випробувальної бази Украӥни питання про якісне та всебічне випробування нових зразків перед прийняттям їх на озброєння стоїть досить гостро. Через це виникає потреба в розробленні таких методів випробувань, які б забезпечували потрібну якість їхнього проведення $i$ дозволяли проконтролювати основні ТТХ РЛС без проведення спеціальних обльотів та без застосування спеціальних засобів. Це стосується пери за все точнісних характеристик РЛС, для визначення яких традииійно використовувалися методи прямого зовнішньотраєкторного вимірювання за допомогою високоточних радіолокаційних та оптичних засобів.

В статті визначені припустимі умови та межі використання методу опосередкованого визначення точнісних характеристик при випробуваннях оглядових РЛС контролю повітряного простору.
\end{abstract}

Ключові слова: оглядові РЛС, випробування, вимірювання, точність, траєкторія, апроксимація.

\section{Вступ}

Постановка проблеми. За останні $5 \ldots 7$ років відбулися значні зрушення в розробленні та оснащенні радіотехнічних військ Повітряних Сил новою радіолокаційною технікою. Розроблені військовопромисловим комплексом України нові зразки РЛС не поступаються кращим світовим зразкам у своєму класі, а піддані глибокій модернізації застарілі масові зразки РЛС доведені до рівня сучасних. На черзі дня - прийняття на озброєння новітніх зразків радіолокаційної техніки. У зв'язку з цим гостро постає питання про якісне та всебічне випробування нових зразків перед прийняттям їх на озброєння. Проведений в [1] аналіз можливостей полігонної бази України 3 проведення випробувань оглядових РЛС доводить їхні обмежені можливості через відсутність належного контрольно-вимірювального комплексу, внаслідок чого якісні випробування РЛС не можуть бути проведені у повному обсязі. У зв'язку з цим виникає потреба в розробці альтернативних методів оцінювання основних тактикотехнічних характеристик РЛС без залучення дорогих комплексів зовнішньотраєкторного вимірювання та спеціальних обльотів авіаційними засобами.

Аналіз останніх досліджень і публікацій. Серед чисельного переліку тактико-технічних характеристик РЛС, які необхідно перевірити під час державних випробувань, найбільш важливими, складними і дорогими у випробуванні є параметри зони виявлення та точності вимірювання координат цілей. Тому необхідна розробка таких методів, які б забезпечували якість випробувань і дозволяли проконтролювати необхідні параметри зони виявлення цілей та точнісні характеристики РЛС без проведен- ня обльотів [2] або при суттєвому зменшенні їхньої кількості [3-4].

Пошук альтернативних методів ведеться досить активно. В роботах [5-6] розглядається можливість використання в сьогоднішніх умовах зовнішніх природних [5] та штучних [6] випромінювачів електромагнітної енергії для визначення зон виявлення цілей радіолокаційними станціями різних діапазонів. В [7] розглядається ітераційний експериментально-розрахунковий метод визначення дальності виявлення повітряних об'єктів (ПО) на різних висотах за даними разових обльотів на певній висоті.

В останні роки широко використовується метод опосередкованого визначення точнісних характеристик РЛС. В документі [8] викладена методика опосередкованого визначення точнісних характеристик РЛС за даними власної згладженої траєкторії неманевруючих або слабко маневруючих цілей. При цьому вважається, що ціль рухається за траєкторією, яка може бути представлена кривою другого порядку, тобто точно апроксимована поліномом другого ступеню. Таке припущення є справедливим, коли мова йде про вимірювання прямокутних координат. Реально ж вимірювання координат повітряних об'єктів здійснюється радіолокаційними станціями в сферичній системі координат. При цьому навіть при лінійному і рівномірному русі об'єкта його дальність та кутові координати змінюються за більш складними законами. Невідповідність законів реальної зміни вимірюваних координат у часі апроксимуючій функції призводить до виникнення похибок апроксимації, які можуть на певних дільницях згладжуваної траєкторії перевищувати навіть похибки вимірювання координат самою РЛС. Отже, в цілому 
позитивна методика оцінювання точнісних характеристик РЛС потребує додаткового визначення умов і меж їі застосування.

Метою цієї статті $є$ удосконалення відомого методу опосередкованого визначення точнісних характеристик РЛС, при якому в якості еталонної траєкторії виступає власна згладжена траєкторія неманевруючих або слабко маневруючих цілей. Удосконалення стосується визначення умов та меж застосування методу для реальних траєкторій польоту повітряних об'єктів і оптимальних обсягів вибірки для згладжування.

\section{Виклад основного матеріалу}

1. Характер законів зміни у часі азимуту та похилої дальності до цілі при їі траєкторному супроводженні.

При застосуванні методу опосередкованого визначення точнісних характеристик РЛС за даними власних згладжених траєкторій на обробку відбирають неманевруючі цілі, тобто ті, які здійснюють рух у просторі на постійній висоті з постійною лінійною швидкістю по ортодромічній траєкторії. При цьому проекція траєкторії польоту цілі на поверхню Землі являє собою пряму лінію, утворену рівномірним переміщенням точки (рис. 1).

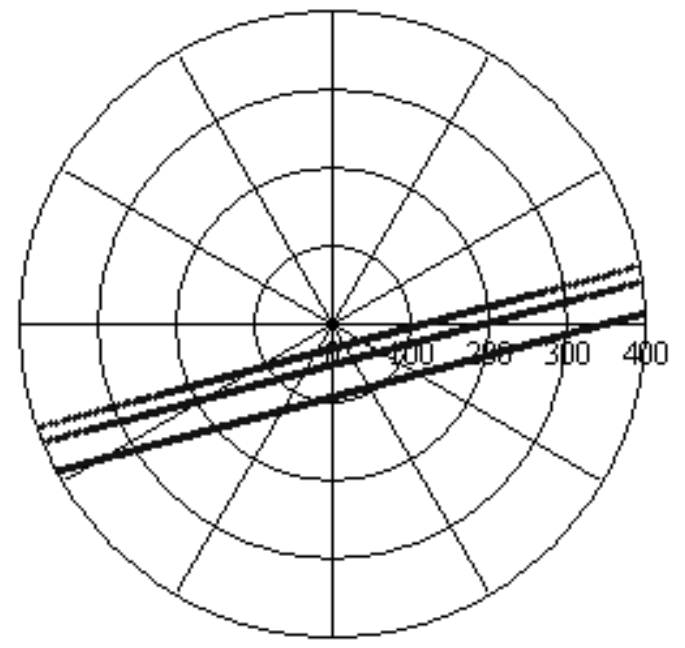

Рис. 1. Вигляд на ІКО РЛС траєкторій прямолінійного рівномірного руху повітряних суден Джерело: розроблено авторами.

Закон зміни координат цієї точки в прямокутній системі координат 3 початком в точці стояння РЛС носить лінійний характер:

$$
\begin{aligned}
& x(t)=x_{o}+V \cdot \sin q \cdot t ; \\
& y(t)=y_{o}+V \cdot \cos q \cdot t,
\end{aligned}
$$

де $x_{o}, y_{o}-$ координати початкової точки траєктоpiï;

$V$ - курсова швидкість повітряного об'єкта; $q$ - курс об'єкта в початковій точці $x_{o}, y_{o}$ траєкторії в системі координат РЛС.

При русі об'єкта по ортодромічній траєкторії його курс постійно змінюється. Тому в розрахунках зручніше перейти до такої постійної характеристики траєкторії, як іiі параметр, і виразити у співвідношенні (1) курс, як функцію від параметра:

$$
q=\arcsin \frac{p}{\sqrt{\frac{2}{o}+y_{o}^{2}}}+\operatorname{arctg} \frac{x_{o}}{y_{o}} .
$$

РЛС здійснює вимірювання похилої дальності та азимуту цілі, закон зміни яких у часі, в припущенні нормальної тропосферної рефракції, визначається співвідношеннями:

$$
\begin{gathered}
r(t)=\sqrt{[x(t)]^{2}+[y(t)]^{2}+\left\lfloor h-\frac{\sqrt{[x(t)]^{2}+[y(t)]^{2}}}{2 R 3 e}\right]^{2}} \\
\beta(t)=\operatorname{arctg} \frac{x(t)}{y(t)}
\end{gathered}
$$

де $h$ - висота польоту цілі;

$R з$ - еквівалентний радіус Землі.

Цілком очевидно, що і залежність (3) (рис. 2), і залежність (4) (рис. 3) не можуть бути описані поліномом скінченного степеню. Мова може йти лише про апроксимацію окремих дільниць траєкторії.

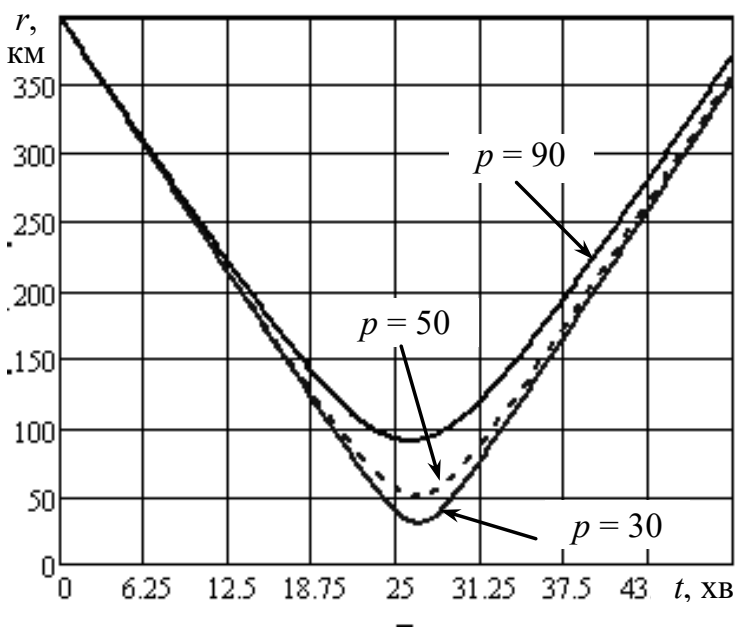

Рис. 2. Закон зміни у часі дальності до цілі за різних значень параметра Джерело: розроблено авторами.

Є дільниці траєкторії, на яких похила дальність i азимут змінюються у часі майже по лінійному закону. Означені дільниці можуть бути апроксимовані лінійною функцією. Дільниці з різким відхиленням від прямої лінії необхідно апроксимувати поліномами більш високих порядків. 


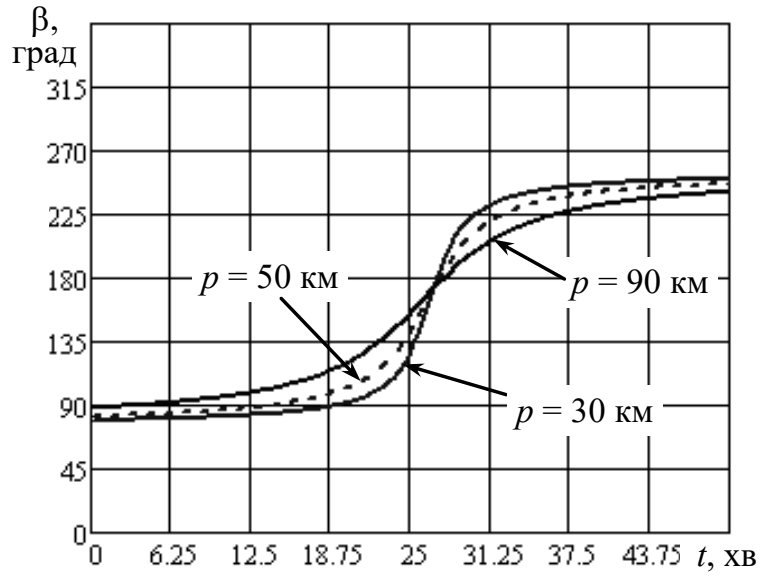

Рис. 3. Закон зміни у часі азимуту цілі за різних значень параметра траєкторії

Джерело: розроблено авторами.

Компромісним варіантом $є$ запропонований в методиці [8] вибір в якості апроксимуючої функції поліному другого ступеню як такого, що є прийнятним і за обсягом обчислювань і здатний відслідковувати слабкі маневри цілі. При такому виборі вважалось, що похибки апроксимації настільки малі, що ними можна знехтувати. Реально ж навіть для неманевруючих цілей закони зміни вимірюваних координат на певних дільницях траєкторії дуже відрізняються від лінійних (див. рис. 2, рис. 3), тому виникає необхідність в дослідженні впливу похибок апроксимації законів зміни вимірюваних координат на результати оцінювання точності вимірювання їх за методикою [5]. Якщо на деяких дільницях траєкторії похибки апроксимації будуть перевищувати певний рівень, то такі дільниці мають бути виключені $з$ обробки.

2. Похибки апроксимації законів зміни у часі азимуту та похилої дальності до цілі.

Одним 3 варіантів вирішення задачі знаходження апроксимуючої функції є використання методу найменших квадратів [9-10].

Згідно з цим методом апроксимуюча функція задається поліномом $m$-го ступеню

$$
Y(t)=A_{0}+A_{1} t+A_{2} t^{2}+\ldots+A_{m} t^{m}
$$

При цьому коефіцієнти $A_{0}, A_{1}, A_{2} \ldots A_{m}$ необхідно визначити так, щоб сума квадратів різниць значень апроксимуючої функції $Y(t)$ і апроксимованої функції $y(t)$ в точках $t_{1}, t_{2}, \ldots t_{n}$ була найменшою:

$$
S=\sum_{i=1}^{n}\left[Y\left(t_{i}\right)-y(t)\right]^{2} \rightarrow \min .
$$

В разі використання в якості апроксимуючої функції поліному другого ступеню

$$
Y(t)=A_{0}+A_{1} t+A_{2} t^{2}
$$

сума квадратів різниць

$$
\begin{aligned}
& S=\sum_{i=1}^{n}\left[A_{0}+A_{1} \cdot t_{i}+A_{2} \cdot t_{i}^{2}-y\left(t_{i}\right)\right]^{2}= \\
& =S\left(A_{0}, A_{1}, A 2\right) \rightarrow \min
\end{aligned}
$$

являє собою функцію трьох змінних $A_{0}, A_{1}$ та $A_{2}$ i набуває мінімального значення, коли часткові похідні по $A_{0}, A_{1}$ та $A_{2}$ дорівнюють нулю:

$$
\begin{aligned}
& \frac{d S}{d A_{0}}=\frac{1}{2} \sum_{i=1}^{n}\left[A_{0}+A_{1} \cdot t_{i}+A_{2} \cdot t_{i}^{2}-y\left(t_{i}\right)\right]=0 ; \\
& \frac{d S}{d A_{1}}=\frac{1}{2} \sum_{i=1}^{n}\left[A_{0}+A_{1} \cdot t_{i}+A_{2} \cdot t_{i}^{2}-y\left(t_{i}\right)\right] t_{i}=0 ; \\
& \frac{d S}{d A_{2}}=\frac{1}{2} \sum_{i=1}^{n}\left[A_{0}+A_{1} \cdot t_{i}+A_{2} \cdot t_{i}^{2}-y\left(t_{i}\right)\right] t_{i}^{2}=0 .
\end{aligned}
$$

Після нескладних перетворень (9) отримаємо систему рівнянь

$$
\begin{aligned}
& A_{2} \sum_{i=1}^{n} t_{i}^{2}+A_{1} \sum_{i=1}^{n} t+n A_{0}=\sum_{i=1}^{n} y\left(t_{i}\right) \\
& A_{2} \sum_{i=1}^{n} t_{i}^{3}+A_{1} \sum_{i=1}^{n} t_{i}^{2}+A_{0} \sum_{i=1}^{n} t_{i}=\sum_{i=1}^{n} y\left(t_{i}\right) \cdot t_{i} ; . \\
& A_{2} \sum_{i=1}^{n} t_{i}^{4}+A_{1} \sum_{i=1}^{n} t_{i}^{3}+A_{0} \sum_{i=1}^{n} t_{i}^{2}=\sum_{i=1}^{n} y\left(t_{i}\right) \cdot t_{i}^{2} .
\end{aligned}
$$

Отримана система рівнянь може бути розв'язана яким завгодно методом, наприклад, методом Крамера [11] чи методом Гауса [12].

Точність апроксимації характеризується або середнім значенням модуля похибки [9]:

$$
\Delta_{\text {anp }}=\frac{1}{n} \sum_{i=1}^{n}\left|Y\left(t_{i}\right)-y\left(t_{i}\right)\right|
$$

або середньоквадратичним значенням похибки (СКП):

$$
\sigma_{\text {anp }}=\sqrt{\frac{\sum_{i=1}^{n}\left[Y\left(t_{i}\right)-y\left(t_{i}\right)\right]^{2}}{n}} .
$$

Оскільки похибки апроксимації будуть порівнюватись 3 середньоквадратичними похибками вимірювання координат, то доцільніше використовувати вираз (12).

За викладеною методикою розраховані похибки апроксимації поліномом другого ступеня законів зміни у часі азимуту та дальності на різних ділянках лінійних траєкторій польоту рейсових літаків цивільної авіації з параметром 30 км, 50 км і 90 км відносно точки стояння РЛС (див. рис. 1) на висотах 10000 м і швидкостях польоту 900 км/год.

Апроксимація здійснювалась методом “ковзного вікна" впродовж всієї траєкторії польоту в межах зони виявлення цілей РЛС. Ширина “вікна" становила 20 регулярних відліків траєкторії (20 обертів антени РЛС). При швидкості обертання антени 6 об/хв поточний розмір ділянки апроксимації ста- 
новить приблизно 50 км. Тобто на обробку надходило 20 значень траєкторії $(n=20)$. Така кількість відліків обгрунтована в п. 3 цієї статті.

Розрахунки доводять, що середньоквадратичні похибки апроксимації закону зміни дальності до цілі у часі (рис. 4) значною мірою залежать від величини параметра траєкторії і можуть сягати кількох сотень метрів на параметрі польоту.

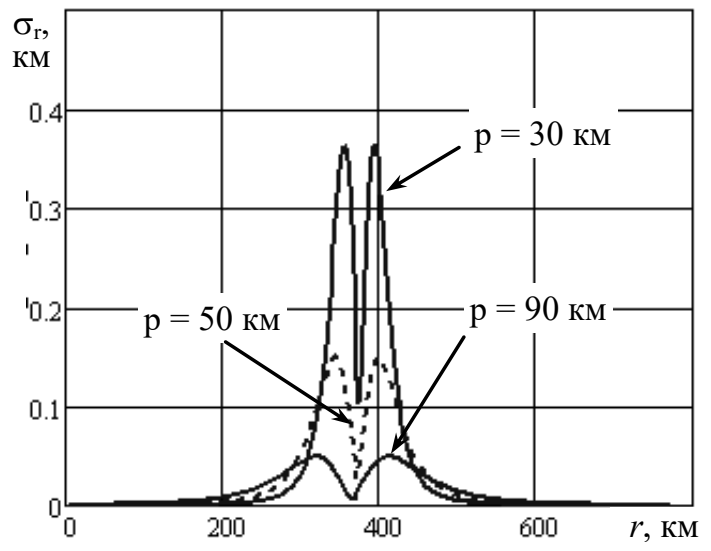

Рис. 4. Залежність СКП апроксимації закону зміни дальності до цілі впродовж траєкторії за різних значень параметра

Джерело: розроблено авторами.

Аналогічна ситуація і $з$ похибками апроксимації закону зміни азимуту цілі у часі (рис. 5). Середньоквадратичні похибки апроксимації закону зміни азимуту цілі на параметрі польоту можуть сягати одиниць градусів.

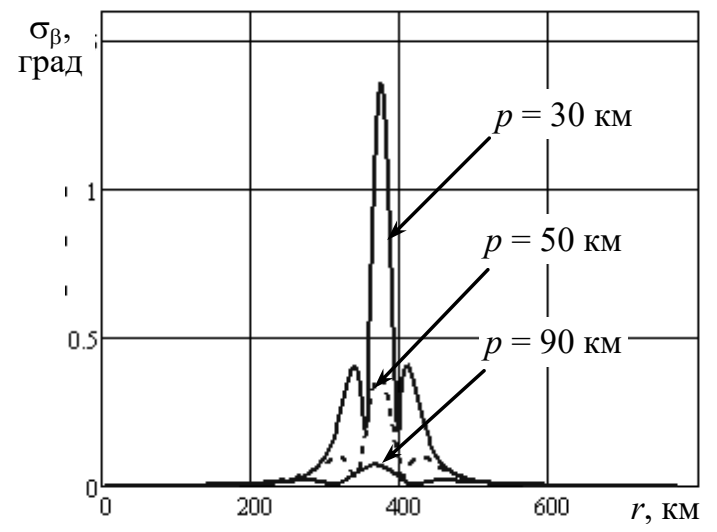

Рис. 5. Залежність СКП апроксимації закону зміни азимуту цілі впродовж траєкторії за різних значень параметра Джерело: розроблено авторами.

Зважаючи на те, що реальні значення середньоквадратичних похибок вимірювання координат сучасними оглядовими РЛС контролю повітряного простору становлять не більше кількох десятків метрів за дальністю і близько 10 кутових мінут за азимутом, необхідно подбати про те, щоб похибки апроксимації були хоча би в $3 . .5$ разів менше. Тобто, припустимі середньоквадратичні значення похибок апроксимації законів зміни координат у часі не повинні перевищувати 10 м за дальністю і 3 кутових мінут за азимутом.

Отже, виходячи з означених щойно вимог і реальних значень середньоквадратичних похибок апроксимації законів зміни координат (див. рис. 4-5), можна констатувати, що при використанні методики опосередкованого визначення точнісних характеристик РЛС за даними власної згладженої траєкторії неманевруючих або слабко маневруючих цілей траєкторії з параметром менше ніж 100 км мають бути виключені з обробки як такі, що спотворюють результати вимірювань. В траєкторіях 3 параметром $100 \ldots 150$ км слід уникати ділянок на параметрі, тобто в області підвищених значень похибок апроксимації. В траєкторіях з параметром більше ніж 150 км при поточному розмірі ділянок апроксимації 50 км похибками апроксимації можна знехтувати.

3. Оптимізація обсягу вибірки при використанні методу опосередкованого визначення точнісних характеристик РЛС.

При використанні методу опосередкованого визначення точнісних характеристик РЛС в якості еталонного вимірювача координат виступає згладжена траєкторія. Припустимо, що закон зміни вимірюваної координати точно відповідає моделі, що закладена в алгоритм згладжування, і похибки апроксимації, розглянуті в п.п. 1, 2, відсутні. Залишаються тільки випадкові похибки вимірювання координат радіолокаційною станцією та похибки згладжування.

Саме така ситуація зображена на рис. 6. Суцільною тонкою лінією зображено істинний закон зміни у часі вимірюваної координати $x(t)$, а жирними крапками - істинні значення координати $x_{i}$ в дискретні моменти часу $i \cdot T_{o}$, тобто в моменти локації цілі. Виміряні радіолокаційною станцією значення координати $x_{i}^{p л c}$ в дискретні моменти часу $i \cdot T_{o}$ позначені жирними хрестиками.

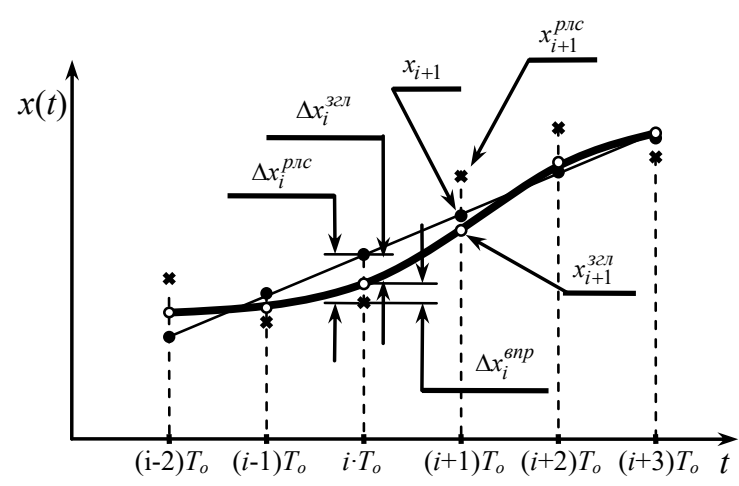

Рис. 6. До процесу визначення похибок вимірювання координат Джерело: розроблено авторами. 
Згладжена траєкторія позначена жирною суцільною лінією, а згладжені значення вимірюваного параметра $x_{i}^{32 л}$ в дискретні моменти часу $i \cdot T_{o}-$ кілечками.

Різниця між істинним значенням координати i виміряним радіолокатором становить похибку РЛС - $\Delta x_{i}^{p л c}$, а різниця між істинним значенням координати і згладженим становить похибку згладжування $-\Delta x_{i}^{32 \pi}$.

Чим більше виміряних значень координати (число $n$ відліків) взято на обробку, тим більше згладжена траєкторія наближається до істинної. При $n \rightarrow \infty$ згладжена траєкторія збігається з істинною.

Відомо [13], що при рівнодискретних, рівноточних та некорельованих вимірюваннях (усім цим вимогам РЛС з регулярним оглядом простору відповідає) і при апроксимації траєкторії руху цілі поліномом другого ступеню похибки згладжування координати залежать від обсягу вибірки $n$ таким чином:

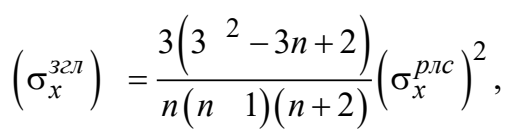

де $\sigma_{x}^{p л c}$ - середньоквадратична похибка вимірювання координати $x$ радіолокатором. Оскільки згладжена траєкторія виступає еталонним вимірювачем, то дисперсія похибок згладжування координати має бути хоча б в $3 \ldots 5$ разів [14] менше дисперсії похибок вимірювання, тобто

$$
\frac{\left(\sigma_{x}^{\text {згл }}\right)^{2}}{\left(\sigma_{x}^{p л с}\right)^{2}}=\frac{3\left(3 n^{2}-3 n+2\right)}{n(n+1)(n+2)} \leq 0,2,
$$

звідки

$$
n \geq 43 \text {. }
$$

Це означає, що довжина дільниці траєкторії, яка б мала лінійний характер, при швидкості польоту цілі $V=900$ км/год. і періоді огляду простору $T_{o}=10$ с повинна бути не менше 100 км. За такої довжини дільниці траєкторії почнуть проявляти себе похибки апроксимації навіть за великих значень параметра траєкторії, що й підтверджують результати моделювання. На рис. 7 та рис. 8 наведені залежності середньоквадратичних похибок апроксимації законів зміни дальності до цілі та азимуту цілі впродовж траєкторії при значенні параметра $p=200$ км і обсязі вибірки в 40 відліків.

Похибки апроксимації закону зміни дальності (див. рис. 7) досягають 40..75 м майже по всій траєкторії, тобто є порівняними з похибками вимірювання дальності самою РЛС, що робить неприйнятним використання згладженої траси в якості еталонного вимірювача координат.

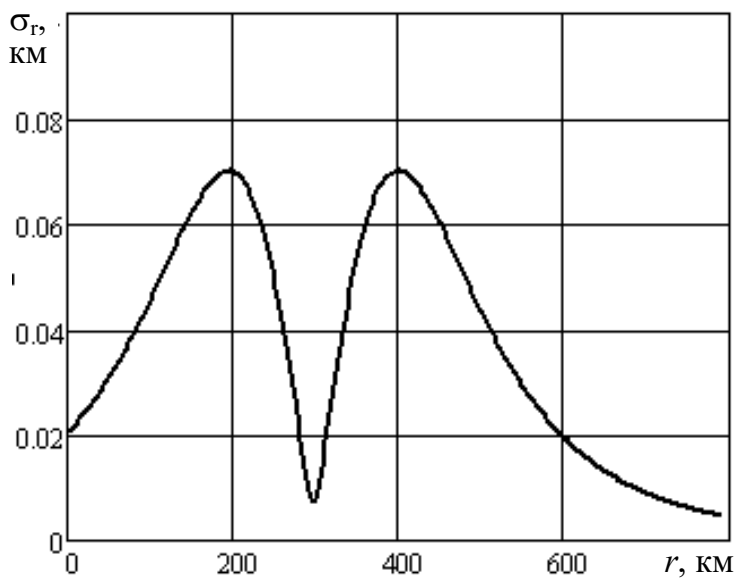

Рис. 7. Залежність СКП апроксимації закону зміни дальності до цілі впродовж траєкторії при $p=200$ км і $n=40$

Джерело: розроблено авторами.

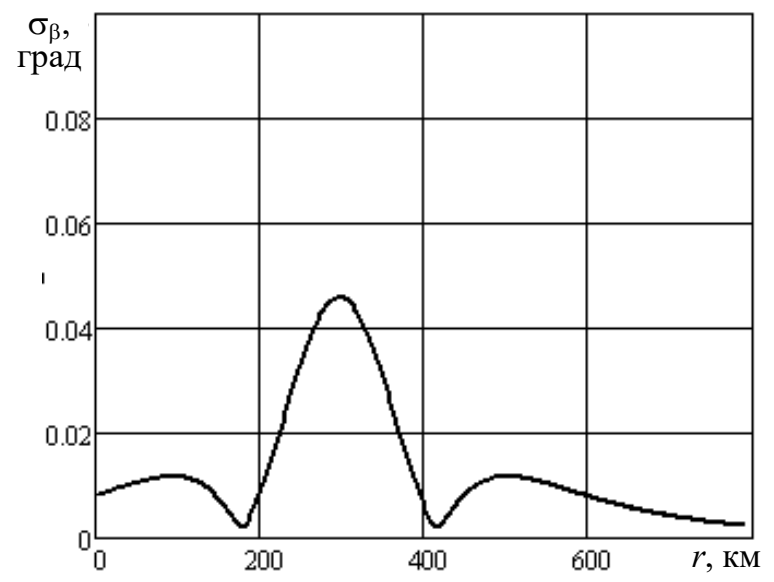

Рис. 8. Залежність СКП апроксимації закону зміни азимуту цілі впродовж траєкторії при $p=200$ км і $n=40$ Джерело: розроблено авторами.

Похибки апроксимації закону зміни азимуту (див. рис. 8) є не настільки значними, але також становлять кілька кутових мінут і $є$ величинами однопорядковими з точністю вимірювання азимуту цілей самою РЛС.

Отже, на обсяг вибірки впливають два суперечливі чинники. Для зменшення похибок згладжування вибірку необхідно брати якомога більшу, а для зменшення похибок апроксимації - навпаки, якомога меншу. Означена суперечність наочно наведена на рис. 9, на якому зображені залежності СКП згладжування $\sigma_{x}^{32 л}$ та середньоквадратичні похибки апроксимації $\sigma_{x}^{a n p}$ при супроводженні цілі по дальності від обсягу вибірки $n$. Крива $\sigma_{x}^{32 л}(n)$ побудована за співвідношенням (13) за умови, що середньоквадратичні похибки вимірювання дальності самою РЛС становлять $60 \mathrm{~m}$, а залежність 
$\sigma_{x}^{a n p}(n)$ отримана шляхом моделювання і являє собою похибки апроксимації закону зміни дальності до цілі на параметрі.

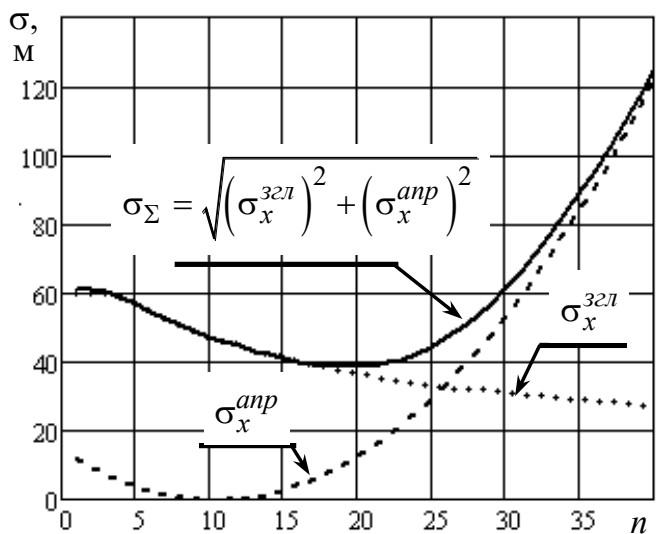

Рис. 9. Залежність похибок згладжування та апроксимації від обсягу вибірки Джерело: розроблено авторами.

Моделювання проводилось для лінійної траєкторії $з$ параметром 150 км при курсовій швидкості цілі 900 км/год. і регулярному огляді простору 3 періодом $10 \mathrm{c}$.

Очевидно, що оптимум настає тоді, коли сума дисперсії похибок згладжування і дисперсія похибок згладжування $\epsilon$ мінімальною. Обсяг вибірки при цьому становить (див. рис. 9) приблизно 20 відліків.

Таким чином, для типових траєкторій польоту рейсових літаків цивільної авіації і при типових значеннях середньоквадратичних похибок вимірювання координат сучасними і перспективними РЛС (дальності - 50..70 метрів і азимуту $10 \ldots 15$ кутових мінут) оптимальним розміром ділянки траєкторії при визначенні їхніх точнісних характеристик в процесі випробувань за результатами супроводження є відрізок в 50 км.

4. Врахування похибок згладжування при визначенні точнісних характеристик РЛС.

Метод опосередкованого визначення точнісних характеристик РЛС передбачає використання в якості еталонного вимірювача координат згладженої траєкторії. Похибки вимірювань визначаються на кожному кроці в межах вибірки як різниця між зладженим і виміряним значеннями координати

$$
\Delta x_{i}=x_{i}^{32 л}-x_{i}^{p л c} .
$$

Але ж (див. рис. 6)

$$
\begin{aligned}
& x_{i}^{\text {злл }}=x_{i}+\Delta x_{i}^{32 л} ; \\
& x^{p л c}=x_{i}+\Delta x_{i}^{p л c},
\end{aligned}
$$

де $x_{i}$ - істинне значення координати на $i$-му кроці (математичне сподівання);

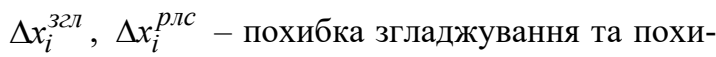
бка безпосереднього вимірювання координати радіолокатором на $i$-му кроці.
Отже,

$$
\Delta x_{i}=\Delta x_{i}^{32 л}-\Delta x_{i}^{p л c}
$$

являє собою різницю двох випадкових величин 3 нульовим математичним сподіванням. Середньоквадратичне відхилення різниці таких випадкових величини визначається, як [15]:

$$
\sigma_{x}=\sqrt{\left(\sigma_{x}^{32 л}\right)^{2}+\left(\sigma_{x}^{p л c}\right)^{2}+2 \rho \cdot \sigma_{x}^{32 л} \sigma_{x}^{p л c}},
$$

де $\rho$ - коефіцієнт кореляції випадкових величин $\Delta x^{32 л}, \Delta x^{p л c}$

$\sigma_{x}^{32 л}, \sigma_{x}^{p л c}-$ середньоквадратичні значення похибок згладжування та вимірювання координат радіолокатором.

При обсязі вибірки в кілька десятків відліків коефіцієнтом кореляції між похибками згладжування та безпосереднього вимірювання координат можна знехтувати, і тоді

$$
\sigma_{x}=\sqrt{\left(\sigma_{x}^{32 л}\right)^{2}+\left(\sigma_{x}^{p л c}\right)^{2}}
$$

В п. 3 цієї статті визначено, що оптимальним обсягом вибірки при опосередкованому визначенні точнісних характеристик РЛС є вибірка в 20 відліків. При цьому похибки згладжування та безпосереднього вимірювання координат радіолокатором за умови згладжування поліномом другого ступеню пов'язані співвідношенням (13) і при 20 відліках

$$
\left(\sigma_{x}^{32 л}\right)^{2}=0,37\left(\sigma^{p л c}\right)^{2}
$$

Підставивши (19) у (18) отримаємо

$$
\sigma^{p л c}=0,85 \sigma_{x},
$$

тобто реальна величина середньоквадратичних похибок безпосереднього вимірювання координат радіолокатором на 15 \% менша за величину, отриману внаслідок використання згладженої траєкторії в якості еталонного вимірювача координат.

\section{Висновки}

1. Основним недоліком методу опосередкованого визначення точнісних характеристик РЛС $€$ ігнорування похибок апроксимації, оскільки вважається, що траєкторії неманевруючих або слабко маневруючих цілей можна точно апроксимувати поліномом другого ступеню. Такий підхід був би справедливим, якби РЛС здійснювала вимірювання координат цілей в декартовій системі. Реально вимірювання координат повітряних об'єктів радіолокаційними засобами здійснюється в сферичній системі координат. Через це навіть для лінійних траєкторій польоту закони зміни у часі дальності до об'єкта і його азимуту не можуть бути апроксимовані поліномом скінченого ступеню і завжди будуть виникати похибки апроксимації, які необхідно враховувати при визначенні точнісних характеристик РЛС. 
2. Найбільш прийнятним варіантом 3 точки зору практичної реалізації методу опосередкованого визначення точнісних характеристик РЛС і можливості врахування слабких маневрів ПО є використання в якості апроксимуючої функції поліному другого ступеню.

3. Для лінійних траєкторій польоту повітряних об’єктів на висотах 10000 м і швидкості 900 км/год. середньоквадратичні похибки апроксимації закону зміни дальності до цілі та азимуту у часі поліномом другого ступеню значною мірою залежать від величини параметра траєкторії і можуть на параметрі польоту ПО сягати кількох сотень метрів по дальності і одиниць градусів по азимуту.

4. Виходячи із зазначених в Т3 на перспективні РЛС вимог до їхніх точнісних характеристик і реальних значень середньоквадратичних похибок апроксимації законів зміни координат при використанні методу опосередкованого визначення точнісних характеристик РЛС за даними власної згладженої траєкторії необхідно:

обирати траєкторії неманевруючих ПО $з$ параметром не менше ніж 100 км, а траєкторії з параметром менше 100 км мають бути виключені з обробки як такі, що спотворюють результати вимірювань;

при обробці траєкторій 3 параметром $100 \ldots 150$ км необхідно вилучати з обробки ділянки на параметрі, тобто в області підвищених значень похибок апроксимації;

в траєкторіях 3 параметром більше ніж 150 км при поточному розмірі ділянок апроксимації до 50 км похибки апроксимації можна не враховувати.

5. На обсяг вибірки при використанні методу опосередкованого визначення точнісних характеристик РЛС за даними згладжених траєкторій впливають два суперечливі фактори: 3 метою зменшення похибок згладжування обсяг вибірки необхідно збільшувати, а для зменшення похибок апроксимації зменшувати. Оптимальним обсягом вибірки є такий, за якого сукупні похибки згладжування та апроксимації $є$ мінімальними. Для траєкторії польоту ПО 3 курсовою швидкістю 900 км/год. при періоді огляду простору 10 с оптимальною є вибірка обсягом в 20 відліків. Розмір ділянки траєкторії при цьому становить приблизно 50 км.

6. При використанні згладженої траєкторії в якості еталонного вимірювача координат отримані значення точнісних характеристик РЛС містять в собі не тільки похибки безпосереднього вимірювання координат радіолокатором, а й похибки згладжування. При обсязі вибірки в 20 відліків реальна величина середньоквадратичних похибок вимірювання координат радіолокатором на 15 \% менша за величину, отриману внаслідок обробки вибірки.

\section{Список літератури}

1. Камалтинов Г.Г. Аналіз існуючої експериментально-випробувальної бази України з випробувань наземних радіолокаційних засобів / Г.Г. Камалтинов, А.А. Курило // 9 наукова конференція Харківського університету Повітряних Сил: Тези доповідей. - Х.: ХУПС, 2013. - С. 149.

2. Савицкий Е.В. Модуль имитации целевой и помеховой обстановки для испытаний радиолокационных станций / Е.В. Савицкий // Радиотехника и электроника: материалы 54-й научной конференции аспирантов, магистрантов и студентов, Минск, 23-27 апреля 2018 г. / Белорусский государственный университет информатики и радиоэлектроники. Минск, 2018. - С. 103.

3. Патент RU2400766C2 Российская Федерация. Способ испытания радиолокационной станции / Гурьев В.П., Лужных C.Н.; заявитель и патентообладатель Открытое акционерное общество "Научно-исследовательский институт измерительных приборов" (ОАО "НИИИП"). - №2008146573/09; заявл. 25.11.2008; опубл. 27.09.2010, Бюл. № 27.

4. Аппаратно-программный комплекс для испытаний загоризонтных радиолокационных станций с использованием метода автоматического пассивного обзора воздушного пространства / С.А. Сорокин, С.С. Свердлов, Ю.С. Кучеров, В.А. Собчук [Електронний ресурс] / С. Сорокин // Вопросы радиоэлектроники. - 2018(5). - С. 17-23. - Режим доступу: https://doi.org/10.21778/2218-5453-2018-5-17-23.

5. Климченко В.Й. Аналіз можливостей використання радіовипромінювання Сонця для зняття діаграм направленості антен сучасних РЛС розвідки повітряних цілей / В.Й. Климченко, Г.Г. Камалтинов, О.В. Бєлавін // Системи озброєння і військова техніка. - 2012. - № 3(31). - С. 63-68.

6. Зюкін В.Ф. Вимоги до віддалення і висоти розміщення імітаторів активних перешкод при полігонних випробуваннях оглядових РЛС / В.Ф. Зюкін, В.Й. Климченко, С.В. Кукобко // Наука і техніка Повітряних Сил Збройних Сил України. - 2018. - №4(33). - С. 52-59. https://doi.org/10.30748/nitps.2018.33.07.

7. Бєлавін О.В. Експериментально-розрахунковий метод оцінки параметрів зон виявлення первинних та вторинних РЛС / О.В. Бєлавін, Г.Г. Камалтинов, О.С. Маляренко // Наука і техніка Повітряних Сил Збройних Сил України. - 2012. - № 3(9). - C. 69-73.

8. Doc. 8071 Manual on Testing of Radio Navigation Aids. Volume III Testing of Surveillance Radar Systems. - ICAO, 1998.

9. Бутырский Е.Ю. Аппроксимация многомерных функций / Е.Ю. Бутырский, И.А. Кувалдин, В.П. Чалкин // Научное приборостроение. - 2010. - Том 20. - № 2. - С. 82-92.

10. Бахвалов Ю.Н. Метод многомерной интерполяции и аппроксимации и его приложения / Ю.Н. Бахвалов. - М.: Спутник+, 2007. - 108 с.

11. Ильин В.А. Линейная алгебра / В.А. Ильин, Э.Г. Позняк. 6-е изд., стер. - М.: ФИЗМАТЛИТ, 2014. - 280 с. 
12. Амосов А.А. Вычислительные методы для инженеров / А.А. Амосов, Ю.А. Дубинский, Н.В. Копченова. - М.: Издательство МЭИ, 2003. - 600 с.

13. Кузьмин С.3. Основы проектирования систем цифровой обработки радиолокационной информации / С.3. Кузьмин. - М.: Радио и связь, 1986. - 352 с.

14. Испытания РЛС / А.И. Леонов, С.А. Леонов, Ф.В. Нагулинко и др.; под ред. А.И. Леонова. - М.: Радио и связь, 1990. $-208 \mathrm{c}$.

15. Вентцель Е.С. Теория вероятностей и ее инженерные приложения / Е.С. Вентцель, Л.А. Овчаров. - 2-е изд. М.: Высш. шк, 2000. - 480 с.

Надійшла до редколегії 23.02.20210

Схвалена до друку 16.03.2021

\section{Відомості про авторів:}

\section{Климченко Василь Йонович}

кандидат технічних наук доцент провідний науковий співробітник Харківського національного університету

Повітряних Сил ім. І. Кожедуба,

Харків, Україна

https://orcid.org/0000-0003-3999-8130

\section{Маляренко Олександр Сергійович}

кандидат технічних наук старший науковий співробітник провідний науковий співробітник

Харківського національного університету

Повітряних Сил ім. І. Кожедуба,

Харків, Україна

https://orcid.org/0000-0003-3268-2803

\section{Бславін Олексій Вікторович}

кандидат технічних наук

начальник відділу Командування Повітряних Сил

Збройних Сил України,

Винниця, Україна

https://orcid.org/0000-0003-4217-2786

Джус Володимир Всеволодович

кандидат технічних наук

доцент Харківського національного університету

Повітряних Сил ім. І. Кожедуба,

Харків, Україна

https://orcid.org/0000-0003-1762-1543

\section{Information about the authors:}

Vasyl Klimchenko

Candidate of Technical Sciences Associate Professor

Lead Research

of Ivan Kozhedub Kharkiv National

Air Force University,

Kharkiv, Ukraine

https://orcid.org/0000-0003-3999-8130

\section{Oleksandr Maliarenko}

Candidate of Technical Sciences Senior Research

Lead Research

of Ivan Kozhedub Kharkiv National

Air Force University,

Kharkiv, Ukraine

https://orcid.org/0000-0003-3268-2803

\section{Oleksii Bielavin}

Candidate of Technical Sciences

Chief of Department of Air Force Command

of Armed Forces of Ukraine,

Vinnytsia, Ukraine

https://orcid.org/0000-0003-4217-2786

\section{Volodymyr Dzhus}

Candidate of Technical Sciences

Senior Lecturer of Ivan Kozhedub

Kharkiv National Air Force University,

Kharkiv, Ukraine

https://orcid.org/0000-0003-1762-1543

\title{
УСОВЕРШЕНСТВОВАНИЕ МЕТОДА ОПОСРЕДОВАННОГО ИЗМЕРЕНИЯ ТОЧНОСТНЫХ ХАРАКТЕРИСТИК ОБЗОРНЫХ РЛС
}

\author{
В.И. Климченко, А.С. Маляренко, А.В. Белавин, В.В. Джус
}

Исходя из ограниченных возможностей полигонной базы Украины по проведению испытаний обзорных РЛС, необходима разработка таких методов испытаний, которые бы обеспечивали нужное качество их проведения и позволяли проконтролировать основные ТТХ РЛС без проведения специальных облетов и без применения специальных средств. Это касается, прежде всего, точностных характеристик РЛС, для определения которых традиционно использовались методы прямого внешнетраекторного измерения с помощью высокоточных радиолокационных и оптических средств.

В статье определены допустимые условия и предель использования метода опосредствованного определения точностных характеристик при испытаниях обзорных РЛС контроля воздушного пространства.

Ключевые слова: обзорные РЛС, испытание, измерение, точность, траектория, аппроксимация.

\section{IMPROVEMENT OF THE MEDIATED MEASURING METHOD OF SURVEY RADARS ACCURACY CHARACTER- ISTICS}

\section{Klymchenko, O. Maliarenko, O. Belavin, V. Dzhus}

Based on the limited capabilities of the Ukrainian polygon base for testing survey radars, it is necessary to develop such test methods that would ensure the required quality of their implementation and allow you to control the main performance characteristics of the radar without special flight tests and without the use of special means. This concerns, first of all, the accuracy characteristics of the radar, for the determination of which the methods of direct external trajectory measurements with the help of high-precision radar and optical means were traditionally used.

In recent years, the method of indirect determination of the accuracy characteristics of the radar from the data of its own smoothed trajectory of non-maneuvering or weakly maneuvering targets has been widely used. In general, a positive method for 
evaluating the accuracy characteristics of a radar requires additional determination of the conditions and limits of its application. The main disadvantage of the method for indirectly determining the accuracy of the radar characteristics is ignoring the approximation errors, since it is believed that the trajectories of non-maneuvering or weakly maneuvering targets can be accurately approximated by a polynomial of the second degree. This approach would be fair if the radar measured the coordinates of targets in a Cartesian system. In reality, the measurement of the coordinates of air objects by radar means is carried out in a spherical coordinate system. Because of this, even for linear flight trajectories, the laws of time variation of the distance to the object and its azimuth cannot be approximated by a polynomial of finite degree and there will always be approximation errors that must be taken into account when determining the accuracy characteristics of the radar.

The article defines the permissible conditions and limits for the use of the method of indirect determination of accuracy characteristics when testing airspace control surveillance radars. It is determined that the sample size when using the method of indirect determination of the accuracy of the radar based on smoothed trajectory data is influenced by two contradictory factors. In order to reduce smoothing errors, the sample size must be increased, and to reduce approximation errors, it must be decreased. The optimal sample size has been determined, which is the volume of 20 samples. With such a sample size, the aggregate errors of smoothing and approximation are minimal.

Keywords: survey radar, test, measuring, exactness, trajectory, approximation. 